\title{
Die teologie in gesprek met die ekonomie
}

\author{
J P Labuschagne \\ Universiteit van Pretoria
}

\begin{abstract}
Theology in dialogue with economics

The purpose of this essay is to explain the development of Western society and its economic foundation, and to offer a Christian ethical evaluation of the different economic structures.
\end{abstract}

\section{INLEIDING}

'n Gesprek van die teologie met die ekonomie moet gesien word as iets normaals vanuit die Christelike etiek se waarneming en beoordeling van alle menslike optrede en skeppinge en so uiteindelik van die samelewingstrukture en die ekonomiese terrein as sodanig. Tog kañ daar bykomend op spesifieke aanleidende faktore gewys word:

- Die moderne samelewing word op 'n ekonomiese basis gebou. Daarom moet 'n beoordeling van die samelewing uiteindelik uitkom by sy ekonomiese basis. Tereg is daarom reeds van die Suid-Afrikaanse samelewing in die onlangse verlede deur Peter L Berger en Bobby Godsell opgemerk: "n Ander soort debat, hoewel dikwels in rasseterme voorgestel, sal die aftakeling van die Suid-Afrikaanse rasgebonde politiek oorlewe en inderdaad oorskadu en dit is die debat oor kapitalisme of sosialisme' (Berger \& Godsell 1988:296; my vertaling).

Hoe die ekonomie in 'n toekomstige Suid-Afrika bestuur gaan word, is daarmee die groot vraag. Sal dit sosialisme of kapitalisme wees?

- Die moderne samelewing word toenemend bewus dat, ter wille van die mens self en die ekologie, dit noodsaaklik geword het dat die etiek weer in werking gestel moet word in die samelewing. Mikro-etiek, as 'n reël vir die individu, is nie meer genoeg nie. Makro-etiek word gevra om die groot probleme van die 
samelewing en sy strukture - sosiaal, polities en ekonomies - aan te spreek (vgl Van Peursen 1975:171-223): 'Alleen wanneer'n mens tot etiese beheersing van strukture kom, kan hy die mag van die strukture in eie hande kry. Maar dan moet ons die strukture nie maar net gelate en sonder teenspraak aanvaar nie. Nee, ons moet léér: leer om juis die vraag na die ontoelaatbare en die etiesonaanvaarbare van die magstrukture te stel' (Van Peursen 1975:201; my vertaling).

Daarmee het die ekonomie ook onder die vergrootglas van die makro-etiek gekom.

- Teoloë word toenemend daarvan bewus - en Suid-Afrika is nie uitgesluit nie dat die imperatief van die Christelike etiek dwing tot 'n verantwoordelike beoordeling van die markplek en die ekonomiese modelle in die samelewing.

J Alex van Wyk stel uitdruklik dat, wat die etiek betref, die kerk dringend hoorbaar moet word in konkrete arbeidsituasies. Vir die gesonde saambestaan van die verskillende belangegroepe in die mark en in die samelewing is dit nodig dat die kerk as vierde deelnemer erken sal word en 'n aktiewe rol sal speel naas werkgewers, werknemers en die staat (Van Wyk 1988:149, 150, 168, 169).

Volgens A F Venter moet die Christelike etiek 'n bydrae lewer tot 'n 'ekonomiese sisteem met 'n etiese grondslag'. Die doel is uiteindelik 'geregtigheid vir almal' (Venter in Vorster 1990:72).

B J van der Walt, direkteur van die Instituut vir Reformatoriese Studie aan die Potchefstroomse Universtiteit, doen 'n oproep vir meer lektuur vanuit die reformatoriese insig oor sosio-politieke en ekonomiese aangeleenthede en beskou dit as 'n dringende noodsaaklikheid (Van die Walt 1988:43-46).

- Ekonome en leiersfigure in die handel en nywerheid vra in groeiende mate na die inset van die etiek, en dan selfs die Christelike etiek, op die markplein.

Die ekonoom M V Kelly (UNISA) wys daarop dat die gemeenskap in die VSA en in Suid-Afrika dit meer en meer as noodsaaklik beskou dat besigheidsbestuurders opgelei behoort te word in die etiek van die markplein. Die betrokkenheid van die teologie word deur die besigheidsgemeenskap gevra en as onmisbaar gesien op die terrein van die besigheidsetiek en die ontwikkeling van opleidingsprogramme in hierdie verband (vgl Vorster 1990:78, 79, 80, 85, 86).

'n Kenner van die ontwikkeling van die Derde Wêreld se ekonomie, en self ook'n ekonoom, Michael P Todaro, sê: 'Dit is daarom uit die staanspoor noodsaaklik dat etiese of normatiewe waarde-uitgangspunte, oor wat verlang word en wat nie, sentrale elemente vorm in die ekonomiese dissipline in die algemeen en van ontwikkelingsekonomie in die besonder' (Todaro 1989:12; my vertaling). 


\section{DIE ONTWIKKELING VAN DIE WESTERSE SAMELEWING TOT 'N SAMELEWING GEBOU OP 'N EKONOMIESE BASIS}

'n Gesprek van die teologie met die ekonomie oor die markplek moet noodsaaklikerwyse die ekonomiese wêreld beoordeel vanuit die werklikheid van sy historiese en samelewingskonteks, anders dreig die gevaar van 'n retoriek wat verval in teorieë met weinig relevansie vir die praktiese opset van 'n samelewing hier en nou. Hiermee kan aangesluit word by Todaro (1989:11; my vertaling):

Anders as die natuurwetenskappe, kan die ekonomie as sosiale wetenskap nie aanspraak maak op wetenskaplike wette of universele waarhede nie. Baie sogenaamde algemene ekonomiese modelle is inderdaad gebaseer op 'n stel blinde veronderstellings oor menslike gedrag en ekonomiese verhoudinge wat weinig of geen verband het met die werklikhede van ontwikkelende ekonomieë nie. In hierdie opsig mag hulle algemeengeldigheid en objektiwiteit meer veronderstel word as wat dit werklikheidswaarde het...Ekonomiese ondersoeke en analises kan eenvoudig nie uitgelig word uit hulle vasgestelde sosiale en politieke konteks nie - veral wanneer 'n mens te doen het met die menslike dilemmas van honger, armoede en swak gesondheid, wat so 'n groot deel van die wèreld se bevolkings teister.

Wanneer die ekonomie in sy historiese en samelewingskonteks geplaas word, is dit baie gou duidelik dat die ekonomie prakties nie altyd suiwere wetenskaplikheid behels nie, maar inderdaad ideologiese konneksies het en as sulks bepaal word deur mense se waardekeuses. Menswees voltrek hom nou eenmaal ook via waardevoorkeure wat van mens tot mens, van groep tot groep, kan verskil, vir sover hierdie waardes verband hou met wat as belangrik beskou word vir 'n sinvolle lewe en 'n samelewing wat die moeite werd is. Daar kan dus nooit slegs een ekonomiese model wees wat vir die waardevoorkeure van elke mens aanvaarbaar sal wees nie. Todaro (1989:12; my vertaling) sê met reg: 'Dit is essensieel dat 'n mens se waarde-uitgangspunte, veral op die gebied van die ontwikkelingsekonomie, altyd duidelik uitgespel word'.

Die Raad vir Geesteswetenskaplike Navorsing kom in 'n studie (1987) tot die konklusie dat die verskillende sosiale wetenskappe in hulle onderskeie metodes, kwalitatief en kwantitatief - en dit sluit onder andere politieke studies en die ekonomie in - nie waardevry en ideologies vry is nie. Hulle ondersteun die standpunt van Kuhn en Quine en verduidelik:

Popper se siening dat wetenskaplikes in staat is om objektiewe en waardevrye beslissings te maak ten opsigte van die teorieë wat hulle 
aanvaar, word bevraagteken deur die werk van Kuhn en Quine. Hulle redeneer dat hierdie soort beslissings oorheers word deur die reëls, norme en oortuigings van die samelewing waarin die ondersoeker werksaam is....

$$
\text { (Van Straaten 1987:80, 81; my vertaling). }
$$

Wanneer in die geskiedenis nagegaan word hoe ekonomiese denke in die samelewing teregkom en hoe dit vanuit die materialistiese oogmerke van belangegroepe, die behoeftes van mense, en selfsugtige idealismes georganiseer en bepaal word, moet uiteindelik in hierdie opsig gekonkludeer word dat die wetenskaplike metode van die ekonomie beslis nie immun is teen ideologiese kontaminasie nie.

Om die ekonomie dus te kan beoordeel vanuit sy historiese en samelewingskonteks, moet gevra word hoe die Westerse samelewing ontwikkel het tot waar hy vandag is - as samelewing gebou op 'n ekonomiese basis. Om hierdie vraag te beantwoord, is dit nodig om die grondmotiewe te identifiseer wat die Westerse samelewing deur die eeue aangedrywe het (vgl Labuschagne 1987:703-1114):

\subsection{Die Grieks-Romeinse samelewing}

Die antieke Griekse filosofie, veral deur die grondliggende riglyne wat deur Plato (427-347 vC) en Aristoteles (384-322 vC) neergelê is, het 'n reuse bydrae gelewer om in die daaropvolgende Grieks-Romeinse wêreld en in die hele opkomende Westerse beskawing 'n samelewing te bou op ' $n$ rasioneel-etiese grondslag, wat moes dien tot die welsyn van alle mense. Laasgenoemde welsyn van alle mense is dan die groot doel.

\subsection{Die Middeleeuse samelewing}

Die Middeleeuse teologie - en dan moet die reuse invloed van Augustinus (354-430 $\mathrm{nC}$ ) en Thomas van Aquinas (1225-1274 $\mathrm{nC}$ ) vermeld word - het aan hierdie rasioneel-etiese grondslag van die samelewing 'n oorheersende Christelike stempel gegee.

\subsection{Die Reformasie-samelewing}

Waar die Middeleeuse skolastiese teologie die Openbaringsinhoud van die Bybel gekompromitteer het met die filosofie van eers Plato en daarna Aristoteles, met groot invloed op die gang van die samelewing, daar het die Reformasie - en dan moet veral na Martin Luther (1483-1546) en Johannes Calvyn (1509-1564) verwys word - anders geoordeel. Die Reformasie het die Openbaringsinhoud van die 
Bybel bevry van sy wèreldfilosofiese kompromieë en 'n onvermengde Christelik-etiese grondslag aan die samelewing gegee, met enorme gevolge vir die samelewingsgang. Die belangegroepe van die Rooms-georiënteerde samelewing sien sy uitweg uiteindelik alleen in 'n gewapende stryd teen die snelgroeiende Reformasie-invloed op die strukture van kerk en samelewing.

\section{4 'n Samelewing op 'n humanisties-rasionele en natuurregtelike grondslag}

Die langdurige godsdiensoorloë wat gevolg het op die Reformasie, het die wêreld in reaksie gebring teen die kerklike invloed in die gang van die samelewing en die deure oopgemaak vir ' $n$ nuwe dominerende invloed in die bepaling van die Westerse samelewing. Die samelewing wat sedert die Renaissance begin ontwikkel, word gebou op 'n humanisties-rasionele en natuurregtelike grondsla ${ }_{\circ}$. Die kerk word in hierdie samelewing op die agtergrond gedruk in 'n oorheersde posisie, verlaag tot die vlak van 'n staatsdepartement. Persone wat na vore tree op die terrein van die samelewing, is byvoorbeeld Johannes Altusius (1557-1638), beskou as die vader van die teorie van die natuurlike reg, Grotius (1583-1645), wat die natuur stel as normatiewe beginsel van die intermenslike regsverkeer en poneer dat die natuurreg "n diktaat van die regte rede' is en John Locke (1632-1704), wie se rasionalisering van die samelewing die beste daarin slaag om uitdrukking te gee aan die wese van die opkomende Britse liberalisme van die sewentiende eeu.

\section{5 'n Samelewing waarin die ekonomie die bepalende posisie inneem}

Die samelewing wat vervolgens ontwikkel, openbaar uitdruklik dat die ekonomie nou verwant is aan ideologiese motiewe.

Aan die einde van die agtiende eeu het die verdere ontwikkeling van die moderne Westerse samelewing nie alleen die konserwatisme van die ancien régime met die Franse Revolusie verwerp nie, maar in die nuwe wat te voorskyn tree, word weldra twee teen mekaar strydende strominge duidelik. Die een wat in Adam Smith (1723-1790) sy vertrekpunt neem, ontwikkel, as oorwinnaars uit die Franse Revolusie, 'n samelewing waarin die materialisme van die nywerheidsbase en die finansiers, sonder kontrolering deur gewete, etiek en owerheid, aanvaarbaar voorgestel word in 'n samelewing gebou op die veronderstelde kompetisie van private individuele hebsug, naamlik liberalisme-kapitalisme. Die een wat in Jean Jacques Rousseau (17121778) sy vertrekpunt neem en as opkomende opposisie uit die Franse Revolusie tree. maar eers in die twintigste eeu substansiële mag in die samelewing bekom, wil die etiek en die gewete weer doeltreffend in werking stel, sodat geregtigheid bepa- 
lend word vir die hele samelewing (sy ekonomiese grondslag ingesluit) en die demokrasie die praktiese instrument word waardeur die doel verwesenlik moet word van die welsyn van die hele gemeenskap, naamlik demokratiese sosialisme.

Intussen het die sondes van die negentiende-eeuse laissez faire kapitalisme (of liberalisme-kapitalisme) in uitbuiting van die arbeiders gelei, ná die radikale reaksie en geboorte van Marxisme-kommunisme - met sy oorsprong in die denke van Karl Marx (1818-1883) - wat 'private gierigheid' as die veronderstelde grondeuwel wil vervang met ' $n$ nuwe materialisme van kommunale besit as hoeksteen van die samelewing.

Die samelewingsmodelle van liberalisme-kapitalisme, demokratiese sosialisme en Marxisme-kommunisme leer uitdruklik dat 'n samelewing op ekonomiese grondslag gebou word, dat al die besonderhede van hoe 'n samelewing ingerig word, altyd in verhouding verkeer tot sy ekonomiese grondslag, wat daardie bepaalde samelewing ekonomies moet moontlik mak en onderhou. Die bestuur van die ekonomie is dus van wesenlike belang vir alle samelewingsmodelle. Hoe die ekonomie bestuur word, bepaal immers wie daarby baat in die samelewing.

\subsubsection{I jberalisme-Kapitalisme}

Die liberalisties-kapitalistiese ekonomiese grondslag skep 'n samelewing wat, met die vrye markkragte van aanbod en aanvraag, met individuele hebsug en kapitaalkrag, met privaatbesit van die produksiewyse en sonder staatsinmenging, enorme rykdomme akkumuleer in min hande, terwyl die breë massas sonder kapitaalkrag en bedingingsvermoë ekonomies veragter en 'n prys moet betaal wat nie altyd verduur kan word nie.

Met hierdie ekonomiese grondslag word 'n samelewing geskep waarin individuele regte en vryhede bepaal word deur kapitaalkrag. Die menigte ontdek uiteindelik dat hulle 'n demokrasie van een-mens-een-stem het, maar met geen invloed en mag op die ekonomiese terrein om daarmee enigsins ' $n$ beter lewensloop te verseker nie. So word 'n beperkte demokrasie daargestel. Politieke vryheid word dan uitgekanselleer onder ekonomiese imperialisme van die monopolie, die kartel en die multi-nasionale besigheidsreuse. (In die RSA beheer - volgens Sake Rapport 1987-02-22 - vier groot monopolieë 83,1\% van die ekonomie, op die grondslag van aandele genoteer op die Johannesburgse Effektebeurs.) Dit is die prys van 'n beperkte demokrasie, waar die owerheidstaak grondliggend beperk word tot justisie, polisie en weermag (en moontlik onderwys), terwyl die kwaliteit van die lewe en die verdeling van welvaart 'n taak van vrye markkragte geword het. Die kern van die kapitalistiese ekonomie is die wedywering van hebsugtige individue op 'n mark, vry 
van enige inmenging deur gewete of owerheid, wat veronderstel is om uiteindelik op dié wyse almal se welvaart die beste te dien. In hierdie ekonomie is die boodskap van die kerk ten opsigte van etiese waardes en norme tegnies-prakties van weinig belang. Die owerheid van die beperkte demokrasie (of liberale demokrasie) is uiteindelik magteloos om die algemene welsyn van die breë bevolking te dien, omdat die beperkte owerheid weinig of geen mag het op die terrein van die mark nie en alleen ingestel is op die handhawing van wet en orde. Die motief hiervoor is daarin geleë dat die vryheid van die individu, binne 'n liberale demokrasie, alleen doeltreffend tot sy reg kan kom wanneer dit prakties die vryheid van die kapitaalkragtige individu behels.

Die veronderstelling, 'wat goed is vir die rykes, is goed vir die armes', is prakties 'n mark wat ongebonde vryheid bied aan die inisiatief en bedingingsmag van die kapitaalkragtiges en dít bied weer gunstige geleenthede vir monopolieë en kartelle om die belange te bevorder van die multi-nasionale besigheidskorporasies (die sg 'big business'), tot nadeel van 'n bevolking wat sonder kapitaalkrag geen bedingingsposisie het as individu op die sogenaamde vrye mark nie. Hierdie bevolking van magtelose vrye individue staan in skerp teenstelling tot die Westerse sosialisme se bevolking van magtige vrye individue, wat gedra word deur hulle vrye assosiasie met 'n effektiewe kollektiewe bedinging in byvoorbeeld vakbonde, koöperasies, verbruikersbewegings ensovoorts en wat uiteindelik gedra word deur hulle kollektiewe mag in die daarstelling van 'n sosialistiese owerheid met 'n kragtige hand wat op alle terreine van die samelewing die algemene welsyn beskerm en bevorder. Laasgenoemde is dan 'n volledige demokrasie in teenstelling met die beperkte demokrasie van die liberalisme.

Wat tot hiertoe gesê is, dui op onuitgespelde ideologiese motiewe wat nie in die rasionalisering van teorieè duidelik na vore kom nie, maar wat wel in die praktyk van samelewings waargeneem kan word.

Wanneer die verbinding liberalisme-kapitalisme gemaak word, verwys liberalisme na die sosio-politieke en kapitalisme veral na die ekonomiese, terwyl dit grondliggend één samelewingsmodel bly, wat groot klem lê op die vryheid en regte van die individu.

Die geestelike verwerking en rasionalisering van die opkomende Britse liberalisme in die sewentiende en agtiende eeu word die beste waargeneem in die werk van John Locke en dan veral in sy 'Two Treatises of Government' van 1690. In die klimaat van liberalisme-kapitalisme het Locke se 'Two Treatises' so algemene inslag gevind dat dit vir William Ehenstein 'die Bybel van moderne liberalisme' geword het (vgl Ebenstein 1969:394; my vertaling). 
'n Groot kenner van Locke, Peter Laslett, verwys na die 'enorme historiese invloed' wat hierdie boek gehad het op die groei van die Engelse liberalisme tot volwaardigheid (vgl Locke 1965:16). Tog vestig Geraint Parry die aandag daarop dat Locke se groot invloed hoofsaaklik op die Engelssprekende wêreld was (Parry 1978:149).

Die Skot, Adam Smith, staan bekend as die vader van die kapitalisme. Hy het in sy beroemde boek 'An inquiry into the nature and causes of the wealth of nations' (1776), 'n boek waaraan hy tien jaar gewerk het en wat by verskyning onmiddellik 'n sukses was, sy politieke ekonomie - en daarmee die welsyn van die hele samelewing - gebou op die hebsugtige instink van die mens. Nog nooit voorheen het iemand so uitdruklik die samelewing en almal se welsyn gebou op die ekonomie nie. Hierdie ekonomie word in die hart van die saak nie bepaal deur etiese beginsels nie, maar deur die private hebsug van die individuele mens aangedryf.

Die onmiddellike sukses van Adam Smith se 'Wealth of Nations' was enersyds te danke aan sy briljante beredenering van die sentrale begrip van die vrye mark en andersyds omdat hierdie werk baie tydig was vir die opkomende industrialiste en fmansiers. Hierdie boek het die regte dinge gesê wat die industrialiste en finansiers wil hoor in hulle strewe na vrywording van Europa se merkantilistiese politieke doeleindes en beheermaatreëls oor die ekonomie - dit was immers 'n doeltreffende rasionalisering van hulle strewe na groot rykdomme.

Met sy verwerping van die merkantilistiese stelsel (waarvolgens die ekonomiese aktiwiteit alleen betekenis het in terme van imperialistiese politieke doelstellings) het Smith die eeue-oue onderdanigheid van die ekonomie aan die politiek beëindig en tegelyk die ekonomie op 'n nuwe koers gestel om voortaan 'n oorheersende invloed uit te oefen oor die hele samelewing.

'Wealth of Nations' was grondliggend 'n studie oor die skepping van rykdom. Vandag nog is die vrye markbeginsels wat in hierdie boek vervat is byna evangelie vir hulle wat 'n brandende begeerte het vir die skepping van groot persoonlike rykdomme. In die bekende boek 4 van 'Wealth of Nations' handel Smith oor ekonomiese groei en redeneer dan vervolgens dat vryheid in die ekonomie lei na die grootste moontlike rykdomme.

\subsection{Marxisme-Kommunisme}

Die Marxisties-kommunistiese ekonomiese grondslag skep 'n samelewing wat met kommunale besit van die produksiewyse en as sodanig met 'n bevels-ekonomie ('command economy') onder staatsdwang die welsyn van al sy burgers bepaal. Die hele bevolking word voorsien van wat hulle nodig het in hulle lewensopset en die breë 
massas is verseker van 'n dak oor hulle kop, voedsel en kleding, maar dit ten koste van individue wie se vryheid aan bande gelê word, individue wie se inisiatief, entrepeneursvermoë en produktiwiteit nie altyd na reg vergoed word nie.

Die Marxisties-kommunistiese ekonomie moet egter ook in sy historiese konteks beoordeel word. Die negentiende eeu word gekenmerk deur die opkoms van die welvarende Westerse industriële state. Die groot industrieë vereis enorme kapitaalinvestering en bring sodoende noodwendig die ekonomiese mag in die hande van 'n klein groepie rykes of kapitaliste. Die groeiende getalle van arbeidermassas skep enorme krotbuurtes in en om die industriële stede. Vanweë die nou opkomende laissez faire-kapitalisme wat geen perke van etiek of gewete respekteer en geen owerheidskontrole oor markkragte aanvaar nie, is 'n grootskaalse eksploitasie van die arbeiders vervolgens aan die orde van die dag. Uit hierdie sondes van liberalisme-kapitalisme wat selfs tot vandag tot op baie plekke nog steeds ongekontroleerd voortgaan, word Marxisme-kommunisme gebore.

Marx het - in voortsetting van insigte wat reeds deur G W F Hegel (1770-1831) aan die lig gekom het - skerp gewys op die 'vervreemding' van die mens in die arbeidsituasie. Ontleding van die industrie-situasie en die bestudering van Adam Smith se uiteensetting van laissez faire-kapitalisme en David Ricardo (1772-1823) se 'labour theory of value', het Marx in staat gestel om die eksploitasie van die een klas deur ' $n$ ander in die gemeenskap duidelik aan te toon. Marx kom tot die slotsom dat die soeke na 'n denkformule waarvolgens die grondbeweging (of drywende kragte) in die samelewing verstaan moet word, nie kan uitgaan van idees en teorieë nie, maar dat ondersoek gedoen moet word na die materiële basis van die samelewing. In die Voorwoord van sy 'Das Kapital' (1867) praat Marx van 'die evolusie van die ekonomiese vorming van die samelewing...as 'n proses van die natuurlike geskiedenis...' (Marx \& Engels 1973:230; my vertaling). In hierdie oortuiging ontwikkel hy sy 'materialistiese konsepsie van die geskiedenis', soos hy dit self genoem het, of soos dit bekend geword het: historiese materialisme. Marx se siening van die geskiedenis hoort hiervolgens tot die familie van ekonomiese interpretasies van die geskiedenis en juis daarom staan sy teorie ook as historiese materialisme bekend.

Volgens Marx is die ekonomie en sy gepaardgaande produksiemasjien die basiese dinamiese krag in die samelewing en geskiedenis. Niemand het duideliker as Karl Marx aangetoon nie dat die hedendaagse samelewing in praktyk effektief deur sy ekonomiese basis gedikteer en uiteindelik gekonstitueer word. Dit beteken dat die ontwikkeling van 'produksiekragte' (masjiene, materiaal, mense, kapitaal ens) deur sy ontwikkeling nuwe 'produksieverhoudinge' tussen mense skep. Eersgenoemde noem hy die 'onderbou' van die samelewing en laasgenoemde die 'bobou' (waaronder tel: politiek, ideologie, kuns, godsdiens, polisie, justisie ens). Wanneer 
die ekonomiese onderbou van 'n samelewing verander, verander dit noodwendig die hele bobou (ideologiese bobou). Soos die tegnologie ontwikkel, word die ekonomiese kragte wat daarmee saamgaan, bepalend tot klassespanning tussen die mense wat bevoordeel word en hulle wat benadeel word. Hierdie klassespanning lei uiteindelik tot revolusie wat noodsaaklik geag word vir nuwe produksieverhoudinge. Op hierdie wyse lei dit voortdurend tot 'n nuwe samelewing. Hierdie proses is histories gedetermineerd totdat die arbeidersklas (die proletariaat) uiteindelik in die finale stadium aan bewind sal kom. Hierdie finale stadium konstitueer die kommunistiese staat waarin die mens tot ware en volledige vryheid sal kom.

Wanneer Vladimir Lenin (1870-1924) Marx se teorie tot praktiese uitvoering bring, maak hy 'n aantal betekenisvolle aanpassings. Volgens Marx kan kommunisme histories-gedetermineerd alleen volg op die hoogbloei van die kapitalistiese industriële staat. Lenin kies die landelike Rusland, wat industrieël ver agter was by Europa. Hy neem ook self inisiatief en is nie bereid om te wag vir historiese noodwendigheid nie. In Lenin se formule tot kommunistiese oorname figureer vier basiese elemente:

- die massa moet gelei word deur die kommuniste party;

- die agtergrond van ekonomiese agterlikheid en wantoestande;

- 'n ontevrede massa;

- revolusionère stryd teen die maghebbers.

Nie die werkersklas is nou die instrument van die revolusie nie (soos by Marx), maar by Lenin neem die kommunisteparty self die inisiatief.

Op die voorpunt van radikalisme, geweld, sabotasie, terreur, terrorisme en revolusie, is die effektiewe prestasie van Marxisme-kommunisme in die twintigste eeu die totstandkoming van staatsburokrasieë waarin bykans die absolute verlies van die vryheid van die mens plaasgevind het. Dit alles gebeur ten spyte daarvan dat Marx voorsien het dat die 'private gierigheid' van die kapitalistiese eksploitasie van die massas (tesis), via revolusie (antitese), opgevolg sou word met volkome vryheid vir almal in die finale stadium van die kollektiewe besit van die produksiewyse (sintese). (Die dialektiese denkskema is opvallend.)

\subsubsection{Demokratiese Sosialisme}

In die propaganda van die kommunisme is demokratiese sosialisme niks anders as 'verbloemde liberalisme' (Berki 1975:11) nie en in die liberalistiese propaganda is alle vorme van sosialisme niks anders as 'kommunisme' (Wassenaar 1977:12) nie. Alhei, liberalisme en kommunisme vrees egter die demokratiese sosialisme vir sy dinamiese strewe na etiese geregtigheid. 
Die demokratiese sosialisme van Wes-Europa word kortliks verduidelik: In sy soeke na etiese geregtigheid in die samelewing openbaar die sosiaal-demokratiese ekonomiese grondslag 'n verbasende openheid, wat voortdurend bereid is om steeds nuwe aanpassings te maak ter wille van 'n ewewig tussen die vnyheid en regte van die individu aan die een kant en aan die ander kant die vryheid en die regte van die gemeenskap. Demokratiese sosialisme handhaaf, soos liberalisme-kapitalisme, 'n markekonomie, waarin die markkragte van aanbod en aanvraag 'n bepalende rol speel, teenoor die bevelsekonomie (of staatsekonomie) van Marxisme-kommunisme wat met staatsdwang die ekonomie bepaal. Tog word die owerheidstaak in die sosiaal-demokratiese samelewing nie beperk tot die grense van 'n beperkte demokrasie nie. Indien nodig, meng die owerheid in in die mark, en die ekonomie word sentraal beplan en gereguleer. Die demokrasie en sy owerheid werk oor die volle wydte van die samelewing, want die doel van die sosiaal-demokratiese samelewing en sy ekonomiese grondslag is die welsyn van die hele bevolking en almal se belange - individu sowel as gemeenskap; dit, terwyl Marxisme-kommunisme die massa bevoordeel en liberalisme-kapitalisme die individuele kapitaalkragtige bevoordeel. Die sosiaal-demokratiese owerheid, in sy soeke na balans ten opsigte van almal se belange, gee markkragte dus nie geheel vry oor aan 'n vir sommige gevaarlike beinvloeding deur grootskaalse individuele kapitaalkrag nie. Sentrale owerheidkontrole en regulering wat die ekonomie betref, wissel, na gelang die omstandighede, iewers tussen volledige nasionalisering (soos by die kommunisme) en volledige privaatbesit (waarna liberalisme-kapitalisme strewe). Dit bevorder demokratiese bedingingsbewegings, wat die omstandighede van die menigtes beskerm, soos koöperasies, vakbonde, verbruikersbewegings ensovoorts, en dit mak gebruik van regstreekse beheermaatreëls, soos loon- en prysbeheer en beheer oor invoer en uitvoer met heffings sowel as kwotas. Dit nasionaliseer dele van die ekonomie wat in almal se belang geag word. Die sosiale demokrasie handhaaf 'n gemengde ekonomie, met steeds nuwe verbindings en nuwe weglatings, met die oog op almal se belang en welsyn. Nasionalisering is vir die huidige minder populêr; vennootskap tussen staat en privaatsektor het gaandeweg as alternatief, onder andere, sy verskyning gemaak.

Die demokratiese sosialisme van Wes-Europa wil sedert die dae van Jean Jacques Rousseau 'n samelewing daarstel en 'n ekonomie ontwerp wat dit moontlik maak en wat ten doel het: Die hoogste moontlike geluk en welsyn vir almal in die land. Om dit te kan bereik, moet die etiek (geregtigheid) ekonomie en samelewing lei. Die groot instrument, waardeur die samelewing prakties moontlik gemaak en in stand gehou moet word, is egter die demokrasie. Daarom meng die demokrasie en sy owerheid, in volksbelang, in alles in en is daar geen gedeelte van die samelewing waarin demokrasie en etiek nie 'n sê het nie, waarin die owerheid uiteindelik nie 'n 
verantwoordelikheid het nie. Die demokrasie is die instrument waarmee die volk beheer uitoefen oor sy lewenslot en toekoms.

\subsection{Konserwatisme}

Die ideologie van die konserwatisme het ná die Franse Revolusie dinamiese aanpassings gemaak om te oorlewe in sy handhawing van kosbare waardes en kultuur vanuit die verlede. Deel van hierdie noodsaaklike aanpassings is dat die konserwatisme hom nie daarvan kan losmaak dat die moderne samelewing ekonomies moontlik gemaak moet word nie. 'n Samelewing word vandag op ekonomiese basis gebou. Omdat die konserwatisme nie 'n eie-ontwerpte ekonomie het wat tiperend van konserwatiewe waardes is nie, mak die moderne konserwatisme gebruik van die ekonomiese beginsels van ander ideologieë. In hierdie verband beweeg die negentiende- en twintigste-eeuse konserwatisme wisselend tussen 'n liberalisties-kapitalistiese en 'n sosiaal-demokratiese ekonomiese basis vir die samelewing. Konserwatisme het nog altyd groot afkeur gehad in die Marxisme-kommunisme.

\section{3. 'N TEOLOGIES-ETIESE BEOORDELING VAN EKONOMIESE STRUK- TURE}

Vir die moderne samelewing wat op 'n ekonomiese grondslag gebou word, bestaan daar tans in hoofsaak drie modelle: liberalisme-kapitalisme, demokratiese sosialisme en Marxisme-kommunisme. In 'n gesprek tussen die teologie en die ekonomie, op basis van die profiel wat hierbo van elkeen van genoemde drie modelle saamgestel is, moet die teologie minstens die basiese probleme aantoon wat die Christelike etiek met hierdie drie modelle het. Wat uit die staanspoor duidelik gestel moet word, is dat die teologie pertinent elke poging mót verwerp wat 'n ekonomiese model (of 'n sosio-politieke model, as dit daarop aankom), voorskriftelik vir alle mense, uit die Bybel wil aflees. Daar bestaan immers gén sodanige voorskrifte in die Bybel nie, omdat die Bybel onder die koepel van sy etiese imperatief aan die mens - as individu en as groep - in 'n eie waardebelewing van die mens, wat van ander mag verskil, die vryheid bied om eie keuses te mag maak. In sy keuses is die mens volledig verantwoordelik binne die ruimte wat daarvoor gestel word in die Christelike etiek - in 'n gelyke inagneming van alle mense, invidue sowel as groepe en hulle belange. Géen model of ideologie het per se enige voorrang nie - hetsy liberalisme-kapitalisme, demokratiese sosialisme of Marxisme-kommunisme, hetsy integrasie of segregasie. In die Christelike etiek het elkeen slegs moontlikhede van aanvaarbaarheid, ten opsigte van bepaalde aspekte. Die teologie weerhou hom van absolute uit- 
sprake ten opsigte van aanvaarding of verwerping in die geheel; oorvereenvoudigings en veralgemenings is tipiese ideologiese en politieke retoriek en gaan mank aan objektiewe wetenskaplikheid. Geen stelsel of model is volmaak of in 'n absolute sin verwerplik nie. Die teologiese etiek evalueer telkens opnuut 'n bepaalde stelling, beginsel, teorie, optrede, tendens of werklikheid en verwerp nooit sonder meer die geheel op grond van die gebreke van 'n onderdeel nie. Dit kompliseer inderdaad enige evaluering, omdat billikheid en regverdigheid en objektiewe wetenskaplikheid vra na noukeurigheid en uitdruklike spesifisering. Oor die tekortkominge van die ekumeniese beweging en die samelewingsteologieë, in hierdie verband, word nie hier gehandel nie.

\subsection{Oorbeklemtoning van die individu ten koste van die gemeenskap}

In die Christelike etiek se gelyke inagneming van alle mense en hulle jelange (groepe sowel as individue), sal die profiel van die liberalisme-kapitalisme uitdruklik wys op die bevoordeling van die individu (spesifiek die kapitaalkragtige individu) bo die gemeenskap (wat by gebrek aan kapitaal en sonder owerheidsinmenging geen bedingingsposisie op die vrye mark het nie).

Adam Smith skrywe sy 'Wealth of nations' (1776) in belang van die kapitaalkragtige individue - die industriebase en die finansiers in hulle strewe na groot rykdomme. Die oorbeklemtoning van die hebsugtige individu en sy belange is telkens op die voorgrond, terwyl die massas op die agtergrond verdwyn.

In boek 2 van sy 'Wealth of nations' is nie etiek of gewete nie, maar die individuele strewe na wins die enigste motief agter ekonomiese bedrywighede: 'Die oorweging van sy eie private profyt is die enigste motief wat die eienaar van enige kapitaal lei om dit aan te wend, of in landbou, in die vervaardigingsbedryf, of in een of ander besondere vertakking van die groothandel of kleinhandel' (Smith 1893:289; my vertaling).

In boek 1 het hy reeds gesê, in uitsluiting van die etiek: 'Dit is nie van die welwillendheid van die slagter, die brouer, of die bakker wat ons ons eetmaal verwag nie, maar van hulle gemoeidheid met hulle eiebelang. Ons beroep ons nie op hulle menslikheid nie, maar op hulle selfliefde...' (Smith 1893:11; my vertaling).

Reg aan die einde van boek 4, nadat hy breedvoering gehandel het oor wat hy beskou as die voordele van 'n perfekte vryheid van owerheidsinmenging in die handel en nywerheid van destyds, stel Adam Smith sy gedagte van 'n beperkte owerheid so:

Elke mens, so lank hy nie die geregswette oortree nie, word volledig vryheid vergun om sy eiebelang op sy eie manier na te strewe en om 
beide sy industrie en sy kapitaal in kompetisie te bring met dié van enige ander mens, of orde van mense. Die vors is geheel en al vrygestel van 'n verpligting...om beheer uit te oefen oor die industrie en private mense en dit te laat ontplooi op 'n wyse wat in die beste belang van die gemeenskap is. Volgens die sisteem van natuurlike vryheid, het die vors alleen drie take...1) Die verantwoordelikheid om die gemeenskap te beskerm teen die geweld en inval van ander onafhank. like gemeenskappe; 2) die verantwoordelikheid om...elke lid van die gemeenskap te beskerm teen...elke ander lid daarvan, of die plig om 'n doeltreffende geregsadministrasie daar te stel; en 3 ) die verantwoordelikheid vir...bepaalde publieke werke en sekere openbare instellings...omdat die profyt nooit die uitgawes kan vergoed nie....

(Smith 1893:540; my vertaling)

Baie bekend is Smith se sin van die 'onsigbare hand' wat die mark sou lei:

Elke individu poog om sy kapitaal so aan te wend dat die produk daarvan die hoogste waarde oplewer...Hy is alleen ingestel op sy eie sekuriteit en alleen sy eie voordeel. En hierin word hy gelei deur'n onsigbare hand om ' 2 doel te bevorder wat geen deel van sy bedoeling uitgemaak het nie. Deur sy eiebelang na te strewe, bevorder hy dikwels dié van die gemeenskap meer effektief as wanneer hy dit werklik sou wou bevorder.

(Labuschagne 1987:702; my vertaling)

Dat die welsyn van die hele gemeenskap die beste gedien word wanneer die hebsugtige instinkte van die mens toegelaat word om ongehinderd sy gang te gaan en alleen beperk te word deur vrye wedywering op die mark en deur die kragte van aanbod en aanvraag, die kenmerkende kapitalistiese teorie, is vir die eise van enige etiek en veral die Christelike etiek, nie goed genoeg nie! Smith het eenvoudig te veel verwag en as vanselfsprekend aanvaar, wanneer hy sou reken dat iets van die etiek in die samelewing en in die gang van die ekonomie tot sy reg kan kom, wanneer hy sy siening van private ekonomie (van wat voordelig is vir die hebsug van die individu) sonder wysiging van toepassing maak op 'n politieke ekonomie ('n samelewingsekonomie waarin dit gaan om die welsyn van almal in die bevolking). Wat nou eenmaal voordelig is vir die kapitaalkragtige individu is beslis nie noodwendig tot voordeel van die arm menigtes nie. Dit lei na 'n opvallende tweeledige soort 'logika' wat vandag deurgaans kenmerkend geword het van die kapitalisme.

Smith, soos reeds aangedui, hanteer hierdie tweevoudige beginsel so dat dit wat voordelig is vir die hebsug van die induvidu, ook voordelig behoort te wees, via die 
werking van die vrye mark, vir die breë menigtes van die gemeenskap. In praktyk baat egter alleen die kapitaalkragtige individu by die vrye mark, waarin niemand hom belemmer nie, terwyl die arm menigtes sonder kapitaal geen bedingingsmag het nie en ewig agterbly. Om hierdie ewige agterbly van die massas te substansieer, hoef net weer gewys te word op wat by 2.5 .1 gesê is oor monopolieê in Suid-Afrika. Een van die grootste eksponente van die hedendaagse laissez faire-kapitalisme, Milton Friedman, erken selfs: 'Die groot gevaar vir die verbruiker is monopolie...' (Friedman 1980:226; my vertaling), maar bly dan in gebreke om aan te toon hoe die volmaakte kompetisie van die vrye mark bereik kan word wat veronderstel is (in hierdie teorie) om die multi-nasionale maatskappye se monopolistiese mag teen te werk.

Gesien die kapitalis se teoretiesering oor 'n ideale perfekte kompetisie op die mark, wat wel nêrens bestaan nie, wys 'n wêreldbekende ekonoom, John Kenneth Galbraith daarop dat die kapitalistiese besigheid nog altyd in praktyk gestrewe het na sy beheer oor pryse en uiteindelik monopolie, omdat hy die onsekerheid van prysskommeling op die vrye mark vrees:

Die grootste bron van onsekerheid...lê in kompetisie en in die vrye en onvoorspelbare beweging van mededingende markpryse. Van die begin af het besigheidsmanne van die moderne kapitalistiese samelewing hulle beywer vir die eliminering of die tempering van hierdie bron van onsekerheid: Monopolie, of die volle beheer oor voorsiening en van hier af oor die prys, deur 'n enkele firma het die hoogste sekuriteit gebied. Maar daar was vele bruikbare moontlikhede op hierdie weg. Prys en produksie-ooreenkomste of kartelle....

(Galbraith 1977:84; my vertaling)

Uiteindelik bly die groot etiese vraag wat aan die kapitalisme gestel moet word: Hoe word ' $n$ stelsel van so veel vir so min geregvendig - waarin buitensporige oormaat slegs in min hande vermenigvuldig? Dit, wanneer byvoorbeeld na die syfers van twee ekonome, Samuelson en Schumacher, gekyk word: 'Die top tien persent van ons rykes kry byna 'n derde van Amerika se totale inkomste en besit meer as die helfte van die totale rykdom...die top een persent besit 25 persent van die Verenigde State se rykdom...' (Samuelson 1976:88; my vertaling).

Waar die VSA slegs 5,6 persent van die wêreld se bevolking uitmaak, verbruik hulle 'snelgroeiende ekonomie' nogtans veertig persent van die wêreld se primère grondstowwe. Die 31 persent mense wat die ryk lande van die wèreld uitmaak, is reeds verantwoordelik vir soveel as 87 persent van die wêreld se energieverbruik (Schumacher 1975:97-110). 
Die cliché 'wat goed is vir die rykes, is goed vir die armes' moet ook teen die agtergrond van die kapitalisme se tweevoudige beginsel gesien word.

In hulle verhouding met die Derde Wèreld het die Eerste Wêreld in hulle ontwikkelingsprogramme hulle deurgaans laat lei deur hierdie kapitalistiese propaganda-cliché. In hierdie verband sê, vanuit sosiaal-demokratiese geledere, die bekende ekonoom, E F Schumacher, wat hom onderskei het met sy ontwikkelingstudies ten opsigte van die onderontwikkelde Derde Wêreld, dat dit tyd geword het om hierdie befaamde filosofie 'te bevraagteken', omdat dit die arm menigtes benadeel: 'Die nuwe denke wat nodig is vir ontwikkeling en hulp sal verskil van die oue, omdat dit armoede ernstig sal opneem. Dit sal nie meganies aanhou sê: "Wat goed is vir die rykes, moet ook goed wees vir armes nie. Dit sal omgee vir mense..."' (Schumacher 1975:141; my vertaling).

Die tweevoudige beginsel kom begryplik ook voor in Clem Sunter se liberalisties-kapitalistiese scenario-beplanning vir Suid-Afrika. Sunter praat van 'n 'tweeledigelogika-ekonomie' (Sunter 1987:88-90). Die 'eerstelogika-ekonomie' is vir hom die ontwikkeling van 'n sterk gesofistikeerde nywerheids-ekonomie (wat 'n geleerde en bekwame groep mense vra, wat gemeganiseerd en gerekenariseerd is). Hierdie ontwikkelde ekonomie mak egter toenemend van minder, maar meer gespesialiseerde mense gebruik. Om massale werkloosheid te bekamp moet 'n 'tweedelogikaekonomie', in samehang met die eersgenoemde ontwikkel word, wat kleinsakebedrywe en die informele sektor aanmoedig en wat veral arbeidsintensief sal wees en wat moet omsien na die massa.

Die hele probleem van spanning tussen ryk en arm in die wêreld word deur Sunter verbygegaan - op die tradisionele liberalisties-kapitalistiese manier moet die armes maar probeer baat by die vryheid van die kapitaalkragtiges in hulle materialistiese strewe.

Die onderskeid wat Sunter in sy 'tweeledigelogika-ekonomie' tref, word vanuit die sosiaal-demokratiese denke van Galbraith beskryf as die planning system (verwysende na die florerende kapitaalkragtige multi-nasionale maatskappye wat omsien na die gelukkige minderheid en wat alles in hulle guns manipuleer met die vrye markstelsel) en die market system (verwysende na die kwynende klein maatskappye en informele sektor wat geen bedingingsvermoe het in die vrye mark teen die kapitaalkragtige monopoliste nie en wat moet omsien na die massa).

Met verwysing na die tweevoudige beginsel, word uitdruklik deur kritici gesê dat op 'n vrye markgrondslag, waar daar geen regstreekse owerheidsinmenging en kontrole plaasvind nie, die liberalisties-kapitalistiese hantering van volgehoue prysstyging (dus inflasie) deurgaans lei na 'n benadeling van die volksmenigtes, die klein maatskappye en die boeregemeenskap en 'n bevoordeling van die kapitaalkragtiges 
en die groot besigheidskorporasies. Galbraith verduidelik hierdie tweevoudige beginsel ten opsigte van die 'beplanningsisteem' en die 'marksisteem' in hierdie verband soos volg:

Die beplanningsisteem word ook min benadeel deur die ortodokse maatreëls vir die bekamping van inflasie - waarvolgens die volgehoue voorrang van die mark aanvaar word. Daar is, om te herinner, drie weë waarvolgens aanvraag dan verminder moet word - owerheidsbesteding moet ingekort word, private besteding uit geleende fondse moet ingekort word en belasting moet verhoog word. Geeneen van hierdie raak die beplanningsisteem ernstig nie. Owerheidsbesteding wat produkte koop van, of direk diensbaar is aan die behoeftes van die beplanningsisteem, kan nie baie ingekort word nie. Hulle het, soos vroeër vermeld, die sanksie van 'n hoër nasionale doel - 'daar kan nie gedobbel word met die nasie se sekuriteit nie'. Gevolglik, indien afgesien moet word van uitgawes, dit uitgestel moet word of ingekort moet word om inflasie te verhinder, dan word die besnoeiing prinsipieel gedoen ten opsigte van besteding aan welsyn, behuising, stedelike dienste, onderwys en soortgelyke sake. Daarmee is die aanvanklike impak van die beperkende begroting nie op die beplanningsisteem nie, maar op die die siviele dienste van die owerheidsektor of op dié van die marksisteem....

Die tweede manier om aanvraag te laat verminder is by wyse van die verhoging van rentekoerse, om daarmee die voorsiening van fondse vir die uitleen van geld te verminder...Dit is van uiterste belang vir die beskermende doeleindes van die tegnostruktuur - die beskerming van sy outonomie - om sy afhanklikheid van geleende fondse tot die minimum te beperk. In plaas daarvan steun dit grootliks vir kapitaal op eie verdienste...Die marksisteem, hierteenoor, steun swaar op geleende fondse. Boere sowel as die klein firmas onder die kleinhandelaars en winkels leen op volgehoue basis. (State, stede en onderwysdistrikte leun ook swaar op geleende fondse.) In behuising en ander konstruksiewerk is hierdie afhanklikheid bykans algeheel. Daarby is die groot maatskappy van die beplanningsisteem, wanneer dit verplig is om te leen, 'n voorkeurkliënt van die banke....

Daarom volg dit nou dat stappe om die rentekoerse te verhoog... ' $n$ radikaal verskillende uitwerking het op die beplanning- en marksisteme. In vergelyking word die firmas in die beplanningsisteem min geaffekteer. In die marksisteem voel hulle die volle impak van die be- 
leid...Dit is lankal reeds opmerklik dat, gedurende periodes van monetêre beperkings...daar baie gekla word deur boere, die residensiële boubedryf, handelaars en ander klein sakemanne. Die groot maatskappy het dan selde klagtes...Die derde manier om aanvraag te beperk is by wyse van verhoogde belasting. Ook hier is 'n verskil in impak tussen die twee sisteme. Die beplanningsisteem het beheer oor hulle pryse waar die marksisteem dit nie het nie. In dié opsig is dit in staat om hoër belasting op hulle produkte en dienste en moontlik ook hoër belasting op hulle inkomste oor te plaas op die koperspubliek en hiertoe is die marksisteem nie in staat nie....

(Galbraith 1974:192-193; my vertaling)

Waarna die multi-nasionale maatskappye strewe, is die akkumulering van groot rykdomme in min hande. Hiervoor is nodig:

* kontrole oor die openbare mening;

- kontrole oor die owerheid; en

* ongebonde vryheid vir homself in die mark.

Galbraith merk hieroor op: 'Die oorlewing van die beplanningsisteem...is afhanklik van sy invloed by en kontrole oor die owerheid...Die invloed van die beplanningsisteem oor die publiek vereis bowenal 'n openbare oortuiging van die belangrikheid van die dinge wat dit doen' (Galbraith 1974:157; my vertaling).

Begryplik is dit nou wanneer Sunter in sy scenario-beplanning van die owerheid se rol ten opsigte van sakebedrywighede meld: 'Die regering moet dus 'n ondersteunende rol speel' (Sunter 1987:44). Wie is dan in beheer?, moet dadelik gevra word. Die antwoord behoort volgens Galbraith, duidelik te wees.

Galbraith het, ten spyte van groot teenstand van aanhangers van die klassieke liberalisme-kapitalisme, ná sy trilogie - 'The affluent society' (1958), 'The new industrial state' (1967) en 'Economics and the public purpose' (1973) groot invloed begin uitoefen op die gang van die moderne ekonomie.

Paul A Samuelson, wêrelderkende leier in die kapitalisme, sè van Galbraith: '... die objektiewe vakkundige moet eenvoudig aanvaar dat ekonomie net nie weer dieselfde sal wees as in die dae voor die Galbraith-trilogie nie' (Samuelson 1976:512; my vertaling).

\subsubsection{Samevattend}

Die besigheidsreuse (die beplanningsisteem) beywer hulle vir die hoogste moontlike wins. Daarvoor is nodig: 
* die uitskakeling van prysfluktuasie deur middel van monopolie en kartel;

* beheer oor die owerheid sodat die owerheid beperk word en nie inmeng met die markkragte en kapitaalkragtiges daaragter nie.

Teen hierdie agtergrond is dit verder vir die beplanningsisteem belangrik om die marksisteem (klein sakebedrywe en die boeregemeenskap) onder te hou met twee baie belangrike instrumente, naamlik:

* hoë insetkoste - veral waar die besigheidsreuse die industrieë beheer wat noodsaaklike stowwe en toerusting verskaf aan kleinsakebedrywe; en

* hoë rentekoerse - veral in die lig daarvan dat besigheidsreuse, anders as kleinsakebedrywe en boerderye, gewoonlik nie geld leen nie en daarom nie geraak word nie.

Die lewenspeil van die breë bevolking word vanselfsprekend ook deur hierdie vier sake wat genoem is, benadeel. Daarmee word die kritiek van die Christelike etiek geregverdig dat die tweevoudige beginsel van liberalisme-kapitalisme in die samelewing die minderheid (die kapitaalkragtige individue) bevoordeel ten koste van die meerderheid (die massa wat geen bedingingsposisie het nie vanweë gebrek aan kapitaal).

Die morele regverdiging van die kapitalisme is ' $n$ aangeleentheid wat na verwagting toemenend op die spits gedryf gaan word (vgl De George \& Pichler 1978: 57-69). Daar word selfs gesê 'dat die opponente van die kapitalisme nie langer sosialisme as die meer produktiewe sisteem van die twee bepleit nie; in plaas daarvan opponeer hulle eersgenoemde as eties onhoudbaar. Indien die vrye ondernemingstelsel verdedig moet word, moet dit op etiese en filosofiese gronde gedoen word' (Vorster 1990:3; my vertaling). Barry voeg by: 'Dit is waar dat in die populêre gesprek die geldigheid van die liberale orde voorgestel word op basis van "regte" en "vryhede", maar dit is ongetwyfeld so dat sy prominente intellektuele woordvoerder tans weining direkte ondersteuning vanuit die etiek probeer daarstel' (Vorster 1990:2; my vertaling).

A D Riley en J A Parsons van die Nasionale Produktiwiteitsinstituut (Pretoria) sê van die kapitalisme: 'Volgens hierdie siening val morele perspektiewe weg. Werk is eenvoudig deel van 'n ekonomiese ooreenkoms; mense werk alleen vir geld, en geen ander verpligtinge is nodig nie. Die wette van aanbod en aanvraag en die onskendbaarheid van die markplek is die enigste determinante' (Vorster 1990:22; my vertaling).

Karl Keating sê dat die belangrikste regverdiging van die vrye markstelsel 'nie herus by sy hoë vlak van materiële produktiwiteit nie, maar by oorweging van die menslike natuur en die behoeftes van daardie natuur' (Vorster 1990:4; my verta- 
ling). Deur meer beslissings oor te laat aan die individu, se Keating, laat die vrye mark mens toe om sy eie morele natuur uit te lewe en welsynsdiens individueel en vrywillig te verrig; 'n mens bewys geen liefdadigheid teenoor 'n ander wanneer die owerheid met dwang materieel van jou wegneem om aan behoeftiges uit te deel nie.

Daar word van kapitalistiese kant, byvoorbeeld deur Keating, geredeneer dat die selfsugtige, bedrieglike en hebsugtige mense nie net in die besigheidswèreld te vinde is nie, maar ook in die regerings van wie die sosialiste verwag dat hulle op 'n beter en regverdiger wyse as die vrye mark (deur inmenging en kontrole) welvaart sal verdeel (Vorster 1990:4). Die stelling het 'n logiese meriete. Tog is dit nie die volle prentjie nie, afgesien van dit wat Pieter le Roux byvoeg: 'Die sentrale argument van die vrye markskool is dat owerheidsmislukkings van 'n veel ernstiger aard is as mislukkings vanweë die mark. Om hierdie rede is dit die beste om die regulering van die meeste sfere van menslike aktiwiteit, met uitsondering van verdediging. sekuriteit en onderwys, oor te laat aan die mark' (Berger \& Godsell 1988:219; my vertaling). In alle billikheid moet geantwoord word dat die volk darem verteenwoordiging het in en daarmee toegang het tot daardie sosialistiese regerings wat die mark en die ekonomie reguleer in almal se belang, terwyl die volk in 'n kapitalistiese opset tog nie verteenwoordiging het in of toegang tot die multi-nasionale besigheidsreuse wat die mark in vryheid manipuleer met kapitaalmag nie. In billikheid mag die vooruitgang en produktiwiteit wat deur die kapitalisme gebring word ook nie gering geskat word nie. P C Potgieter en J H Smith sou byvoeg: 'Maar die Bybel se naasteliefde eis wel ' $n$ veel ewerediger verspeiding van besittings as wat tans in die kapitalistiese samelewing dikwels die geval is. 'n Samelewing waarin sommige tot vermorsens toe in matelose weelde lewe terwyl ander onder die broodlyn is, kan Christelik nie verantwoord word nie' (Potgieter \& Smith 1988:77, 78).

Ten slotte kan daarop gewys word dat teoloë wat kenners is van die Derde Wèreldsituasie, pertinent sê dat die ryk Eerste Wêreld hulle ekonomies-voordelige posisie handhaaf deur die Derde Wèreld in ekonomiese afhanklikheid te hou (Kee 1974:93; Gutierrez 1974:84, 85).

Dit is in elk geval logies dat waar liberalisme-kapitalisme die multi-nasionale besigheidsreuse bevoordeel (soos hierbo reeds verduidelik) en hierdie maatskappye in die Eerste Wêreld gesetel is, dat hierdie stelsel uiteindelik die Eerste Wêreld bevoordeel ten koste van die Derde Wéreld. Die tweevoudige beginsel bepaal dus ook die verhouding van die Eerste Wêreld tot die Derde Wêreld en plaas laasgenoemde in 'n afhanklikheidsposisie, omdat laasgenoemde by gebrek aan kapitaal. krag geen bedingingsposisie het nie. Wat Suid-Afrika in die toekoms betref, sal die voordeel vir die Eerste Wèreld daarin geleë wees om noodsaaklike grondstowwe goedkoop te bekom wanneer Suid-Afrika in 'n afhanklikheidsposisie (dus in 'n Der- 
de Wêreldposisie) gehou kan word. In hierdie verband kan verwys word na die internasionale Brandt-Verslag en die werk van Robert Cassen, Richard Jolly, John Sewell, John Mathieson en dié van Sinclair en Parker (vgl Labuschagne 1987:10121020).

Die gevaar dat die VSA hom wend tot 'hulpbronne-oorloē' in Suidelike Afrika word nie uitgesluit nie (Cassen, Jolly et al 1982:62).

Op makro-etiese vlak verwerp die teologie hierdie bevoordeling van die Eerste Wêreld ten koste van die Derde Wêreld. Die Suid-Amerikaanse Roomse teoloog, Camilo Torres sê: 'Die kapitalistiese mentaliteit sien ons in die begeerte na die maak van wins sonder om ag te slaan op die belange van die gemeenskap' (Torres 1969:147; my vertaling).

\subsection{Oorbeklemtoning van die gemeenskap ten koste van die individu}

In die Christelike etiek se gelyke inagneming van alle mense en hulle belange (individue sowel as groepe), sal die profiel van die Marxisme-kommunisme uitdruklik wys op die bevoordeling van die gemeenskap (beskerm deur owerheidsdwang) bo die individu (wie se inisiatief, entrepreneursvermoë en produktiwiteit nie altyd na reg vergoed word nie).

Reeds Hegel se staatsfilosofie, in sy 'Grundlinien der Philosophie des Rechts' (1821), het die indidvidu en sy belange laat opgaan in die staatsgemeenskap. Die staatsgemeenskap het dus groter klem as die individu. Vir Hegel kan die vryheid van die mens (die individuele mens) alleen tot volle vryheid kom in die staat, waar moraliteit in sosiale sedelikheid sy volheid bereik. So sê Hegel dan:

" 'Die staat is die werklikheid van die sedelike idee' (Hegel 1955:207; my vertaling).

- 'Die staat is die werklikheid van die konkrete vryheid' (Hegel 1955:214; my vertaling).

- '...die konkrete vryheid bestaan egter daarin dat die persoonlike individualiteit en sy besondere belange nie alléén hulle volledige ontwikkeling en die erkenning van hulle reg bereik lin die sisteme van die familie en die burgerlike samelewing] nie, maar ook uit eie beweging gedeeltelik in die belange van die algemene oorgaan, deels met wete en wil dieselfde en dit inderdaad as hulle eie substansiële gees erken en dit vir dieselfde as hulle einddoel opneem en daarvorr werk...' (Hegel 1955:214, 215; my vertaling).

In die geheel gesien, is die staat (in sy siening van die staai) vir Hegel die redding uit die byna chaotiese dialektiek van die liberale burgerlik samelewing (liberalismekapitalisme). In die dialektiese denke van Hegel lei die vryheid van enkelinge (in 
die gesin) via die vryheid van weiniges (in die liberale burgerlike samelewing) na die vryheid van almal (in die staat). Tog het Hegel nie die markekonomie verwerp nie - al staan hy vir staatskontrole oor die ekonomie - en het hy in sy 'Randbemerkungen' van sy 'Grunlinien der Philosophie des Rechts' private eiendom beskrywe as 'mein Recht als Person' (Hegel 1955:331).

Hegel sê: 'Waar my wil as persoonlike sowel as individuele wil vir my objektief word in eiendom, verkry eiendom so die karakter van private eiendom...' (Hegel 1955:58; my vertaling).

Marx sien duidelik die samelewing as bepaal deur sy ekonomiese basis; in sy 'Bydrae tot die kritiek op die politieke ekonomie' (1859) sê hy:

Ek is deur my studie gelei tot die konklusie dat regsverhoudinge sowel as staatsvorme nie een op sigself verstaan kan word of verduidelik kan word deur die sogenaamde algemene ontwikkeling van die menslike denke nie, maar dat hulle gewortel is in die materiële omstandighede van die lewe...die anatomie van daardie burgerlike samelewing moet gesoek word in die politieke ekonomie.

(Marx \& Engels 1971:84; my vertaling)

Karl Marx sê dat die staat (wat deel is, saam met die polisie, justisie en militêre mag, van die ideologiese bobou) in die volledige kommunistiese samelewing sal verdwyn, omdat die staat se funksie tevore daarin geleë was om ondersteuning en beskerming te bied aan watter eksploiterende klas ook al die produksiewyse (die ekonomie) in die hande gehad het. In die kommunistiese samelewing word die produksiewyse kollektief besit; privaatbesit is dan afgeskaf. Klasseverdeling en eksploitasie sal op grond hiervan verdwyn. Die mens as sosiale wese tree nou veel sterker as by Hegel na vore en in die kommunistiese samelewing sal hierdie mens tot sy reg kom in die ware ryk van die vryheid (vgl McLellan 1973, 1974). In 'Die Heilige Familie' wat Marx en Engels in 1845 geskrywe het, word gesê:

Indien dit korrek verstaan word, is belange die grondbeginsel van alle sedelikheid en moet die mens se private belange daartoe gebring word om saam te val met die belange van die mensdom...Indien die mens gevorm word deur sy omgewing, moet sy omgewing menslik gemak word. Indien die mens van nature sosiaal is, sal hy sy ware natuur alleen in die samelewing ontwikkel en die krag van sy natuur moet nie deur die krag van afsonderlike individue gemeet word nie, maar deur die krag van die gemeenskap.

(Marx \& Engels 1964:67, 68; my vertaling) 
Marx se 'Kritiek op die Gotha program' (1875) het 'n sentrale posisie verower in die denke van Lenin en daaropvolgende sowjetgeskrifte. Veral één beroemde sin was van enorme betekenis in die vorming van die kommunistiese samelewing en veral sy ekonomiese basis en in die bepaling van 'n ontwikkelde produksie-opset en kollektiewe welvaart: 'Van elkeen volgens sy bekwaamheid, aan elkeen volgens sy behoeftes!' ('Jeder nach seinen Fähigkeiten, jedem nach seinen Bedürfnissen!' - Marx \& Engels 1971:160).

Hierdie beskouing het die kern van die kommunistiese ekonomie bepaal en so voedsel, kleding, 'n dak oor die kop en algemene versorging vir die massas gebring. Maar hierdie beskouing dra ook die kiem van die ondergang van die kommunistiese samelewing: Nooit voorheen is die gemeenskap so bevoordeel ten koste van die individu (en individuele vryheid) nie. En dit is Christelik-eties totaal onaanvaarbaar. Die ingrypende verandering wat tans plaasvind in kommunistiese state dui op die inherente swakheid van hierdie beskouing; daar is ontdek dat ' $n$ groot deel van die massa slegs behoeftes het wat parasiteer op die bekwaamhede van 'n klein produktiewe groep en dit moet tans reggestel word.

Hierdie toedrag van sake word duidelik wanneer Mikhail Gorbachev self aan die woord gestel word: Volgens 'n nuusberig van die SAUK (1991-07-26; 08:00) het Gorbachev gesê dat 'die Kommumiste Party moet ophou om net die werkersklas te verteenwoordig'. In sy Perestroika (1988) praat Gorbachev van die 'radikale verandering van die bestuur van die ekonomie' en van 'die noodsaaklikheid van 'n radikale hervorming van die ekonomiese meganisme en van 'n herstrukturering van die hele bestuursisteem van die ekonomie' (Gorbachev 1988:83, 84; my vertaling). Verder:

Wat is die groot terkortkoming van die ou ekonomiese meganisme? Dit is bo alles die gebrek aan innerlike aansporing vir selfontwikkeling...die werknemers se inkomstes is nie afhanklik van die eindresultaat van die kollektiewe arbeid nie: die uitvoering van kontrakverplig. tinge, die kwaliteit van produkte, en prołyte. So 'n meganisme, kan verwag word, sal gemiddelde of selfs swak kwaliteit in arbeid oplewer, of ons daarvan hou of nie. Hoe kan die ekonomie vooruitgaan wanneer dit begunstigde toestande vir agterlike ondernemings skep en vooruitstrewende ondernemings benadeel?

Die nuwe ekonomiese meganisme moet sake regstel...Ondernemings moet in omstandighede geplaas word wat ekonomiese kompetisie aanmoedig tot die beste bevrediging van verbruikersaanvraag en werknemers se inkomstes moet streng afhanklik gemaak word van eindproduksie-resultate, van wins. 
...Daar was byvoorbeeld die mening dat ons moet ophou met 'n beplande ekonomie en werkloosheid moet sanksioneer. Dit kan ons egter nie toelaat nie, omdat ons doel is om sosialisme te versterk en nie om dit te vervang met' $n$ ander soort sisteem nie. Wat ons uit die Weste aangebied word, van 'n ander soort ekonomie, is vir ons onaanvaarbaar...sosialisme kan baie meer bereik as kapitalisme.

(Gorbachev 1988:85, 86; my vertaling)

Verder praat Gorbachev (1988:84-87; my vertaling), onder andere van die volgende nuwe dinge:

" " $n$ hervorming in die sisteem van prysbepaling';

- 'die herstrukturering van buitelandse ekonomiese bande';

- 'die ontwikkeling van die demokratiese grondslag van bestuur';

* 'beginsels vir self-bestuur';

- "n moderne model van 'n sosialistiese ekonomie'.

Daarby meld hy dat die Oppersowjet hom reeds uitgespreek het ten gunste van 'die beleid vir die bevordering van die mense se aktiewe betrokkenheid by ekonomiese en produksie-prosesse en waarvolgens die belange van die staat nou verbind word met dié van die individu en gesamentlike arbeid en waarvolgens die sowjetarbeiders die ware meester sal wees' (Gorbachev 1988:87; my vertaling).

Die groot probleem en swakheid van die Marxisties-kommunistiese ekonomie is eties dus dat 'n behoeftige en onproduktiewe massa parasiteer op die harde werk, vindingrykheid en bekwaamheid van die produktiewe individu. Hierdie individu se vryheid en sinvolle lewensruimte word inderdaad daarmee belemmer en ingekort. Eties word sy lewensruimte daarmee versmoor en geweld aangedoen.

Waar Suid-Afrika tans in 'n stroomversnelling op pad na 'n nuwe opset beland het, kan 'n kommunisme enger as die oorspronklike kommunisme hom tref wanneer 'n samelewing geskep word waarin swart massas se verwagtinge slegs materiële behoeftes sonder produktiewe arbeid, ten koste van 'n blanke minderheid se ondernemerskap en produktiwiteit, behels. Nie alleen sal 'n gelyke inagneming van almal se belange ontbreek nie, maar tegelyk sal die blanke minderheid se vryheid en lewensruimte daardeur strukturele geweld aangedoen word. Persoonlike belasting wat vinnig groei en swaar op die blanke individu leun, wys reeds die laaste aantal jare in hierdie rigting. Finansies en Tegniek (1989-05-19:7) het byvoorbeeld daarop gewys dat die blanke bevolking van Suid-Afrika, wat minder as 25 persent van die totale bevolking uitmaak, reeds 92,9 persent van die land se belasting betaal.

Indien die swart bevolking se verwagtinge alleen deur behoeftes bepaal gaan word en nie deur produktiewe arbeid nie, kan hierdie onetiese opset tot gevolg hê 
dat groot getalle blanke professionele, bekwame en welvarende persone die land verlaat. Dit sal alleen agteruitgang versnel. Ook S J Terreblanche waarsku teen emigrasie van 'professioneel-geskoole witmense' (Kinghorn e a 1989:17).

Louw en Kendall wys selfs die sogenaamde 'affirmative action', om integrasie met wette en regulasies af te dwing, af as 'n soort omgekeerde rassisme: 'fashionable racism'. Hiervolgens word firmas byvoorbeeld met wette en regulasies gedwing om 'n sekere persentasie swart werknemers in diens te neem teen gelyke betaling en minimum lone. Die vryheid om te assosieer en te disassosieer word geskend en die vryheid word ' $n$ werkgewer ontneem om te verwag dat vergoeding verband hou met werklikhede soos kwalifikasies, bekwaamheid en produktiwiteit (Louw \& Kendall 1986:103-107).

W Breytenbach en H J Kotze wys daarop dat die Eerste Wêreld se multi-nasionale besigheidskorporasies nie weer in Afrikalande investeer het nadat swart meerderheidsregerings eers oorgeneem het nie (Kinghorn 1989:Voorwoord, 1, 23). Ongeskooldheid, 'n onstabiele arbeidersmark, gebrek aan produktiwiteit en onstabiele regering is sekerlik faktore wat genoem kan word. Is produktiwiteit nie in laaste instansie die weg tot vooruitgang nie?: 'As iemand nie wil werk nie, moet hy ook nie eet nie' (2 Tess 3:10).

W Verwoerd waarsku: '..waarskynlik Afrika se grootste dilemma - 'n bevolkingsontploffing' (Kinghorn e a 1989:35). Ekonomies staan dit vas dat daar 'n verband is tussen welvaart, wat 'n bodem kan oplewer en die getalle van 'n bevolking. Verder is, vanuit ' $n$ Christelik-etiese oogpunt gesien, ' $n$ bandelose bevolkingsaanwas van een groep mense ten koste van 'n ander groep, geweld teen die lewe en sinvolle lewensruimte van 'n medemens. Waar rasseverskille voorkom, soos in Suid-Afrika, kan dit ook dui op 'n vorm van rassisme.

Waarteen ons teen hierdie agtergrond moet waak, sal die teologiese etiek in gesprek met die ekonomie telkens sê, is ' $n$ ekonomiese basis wat 'n samelewing in stand hou waar die massa bevoordeel word ten koste van die individu en die minderheid. Die ervaring van die kommunistiese lande is tans besig om die wêreld te wys op die les wat hulle geleer het in hierdie verband.

\subsection{Die middeweg}

In die Christelike etiek se gelyke inagneming van alle mense en hulle belange, sal die profiel van die demokratiewe sosialisme moontlik die naaste kom aan die eise van die imperatief - en wel in hulle voortdurende soeke na 'n ewewig tussen die vryheid en regte van die individu aan die een kant en die vryheid en regte van die gemeenskap aan die ander kant. Daarby kan gevoeg word: hulle handhawing van 
die etiek en doel van elke mens se welsyn. Dit is daarom ook nie 'n verrassing nie wanneer van die groot teoloë van ons tyd simpatie met die demokratiese sosialisme openbaar. So skrywe Karl Barth byvoorbeeld in 1933 in 'n brief aan Bonhoeffer: 'Ek het 'n brief geskrywe aan minister Rust...waarin ek hom vertel het dat ek nie bereid is om die sosiaal-demokrate te verlaat nie...' (Bonhoeffer 1974:203; my vertaling). Die ekonoom, Grossman, merk in hierdie verband op: "n Verdere balangrike ideologiese bron van die demokratiese sosialisme was tot dusver die etiese onderrig van die verskillende Christelike [veral Protestantse] godsdienste' (Grossman 1974: 51; my vertaling). Tog, gedagtig aan die menslike swakheid, staan die middeweg altyd in die gevaar om in sy soeke na ewewig ook die oortredings van die een kant of die ander kant te herhaal: hetsy die liberalisme-kapitalisme se bevoordeling van die kapitaalkragtige individu, of die Marxisme-kommunisme se bevoordeling van 'n onproduktiewe massa. Nietemin, die teologie maak nie 'n keuse vir slegs één model van die ekonomie (of die samelewing) nie. Die teologie beoordeel spesifieke sake vir hulle etiese aanvaarbaarheid.

Demokratiese sosialisme se strewe na etiese geregtigheid en ewewig tussen die vryheid en regte van die individu teenoor dié van die gemeenskap, het veral in Rousseau sy oorsprong (in bv sy 'Verhandeling oor die Politieke Ekonomie'): 'Die samelewing is daarom ook ' $n$ morele persoonlikheid met ' $n$ wil; en hierdie algemene wil, wat voordurend ingestel is op die bewaring van die welsyn van die geheel en van elke individu...stel vir alle lede van die staat...die reël vas van wat regverdig en onregverdig is...' (Rousseau 1963:236, 237; my vertaling); en:

Wat in die regering absoluut noodsaaklik is en miskien die moeilikste, is 'n onbuigsame integriteit in die uitvoering van 'n strenge geregtigheid teenoor almal en bowenal in die beskerming van die armes teen die tirannie van die rykes. Die grootste euwel het alreeds plaasgevind wanneer daar armes bestaan wat verdedig moet word en rykes wat bedwing moet word...Dit is daarom een van die belangrikste funksies van die owerheid om uiterste materiële ongelykheid te verhoed....

(Rousseau 1963:250)

Insiggewend, is Pieter le Roux - een van diegene wat twyfel of liberalisme-kapitalisme 'n kans het om te slaag teen demokratiese sosialisme - se standpunt wanneer daar onderhandel word oor die toekoms van Suid-Afrika. Hy sè: 'In hierdie gedeelte word oorweging gegee aan die mate waarin 'n sosiale demokrasie kan voldoen aan die ekonomiese verwagtinge van die verskillende groepe in Suid-Afrika. Die konklusie is dat dit die enigste tipe van sisteem is wat uit 'n onderhandelde ooreenkoms kan kom, onder die huidige omstandighede' (Berger \& Godsell 1988:224; my 
vertaling). Verder noem hy die sosiale demokrasie 'n 'ongemaklike kompromie' (Berger \& Godsell 1988:223; my vertaling).

In 1980 het John Kane-Berman in 'n artikel in Frontline (Des 1980), onder die opskrif, 'Capitalism: A Licence to Exploit', 'n sosiaal-demokratiese ekonomie nodig geag vir die opbou van Suid-Afrika. Wat hy as noodsaaklik beskou, is 'dat die staat moet intree, 'n groter eerder as 'n kleiner deel van die nasionale hulpbronne toeeien, en optree as die uitdeler van sosiale geregtigheid in die tradisies van die sosiale demokrasie' (my vertaling).

Dat die middeweg nie so eenvoudig is nie, is reeds gesê. Om die 'ekonomiese lewe tussen die twee uiterstes' van kapitalisme en kommunisme 'deur te stuur', het die teoloog, Emil Brunner, 'n waardevolle woord gespreek:

In die Christelike geregtigheidsbeginsel lê twee dinge veranker: die vryheid van die enkeling en die verantwoordelikheid teenoor die gemeenskap. By die kollektivistiese ekonomie gaan die vryheid onder. By die individualistiese ekonomie gaan die verantwoordelikheid teenoor die gemeenskap onder...Die Christelike gemeenskapsgedagte het met die kommunisme...ewe weining te doen as die Christelike vryheid met die kapitalistiese liberalisme...Maar die kommunisme, dit wil sê 'n deur die staat van 'n dwingende reg voorsiene en allesomvattende reëling van die ekonomie, is iets heel anders. Dit is 'n karikatuur van 'n Christelike gemeonskap, soos die kapitalistiese individualisme 'n karikatuur van Christelike vryheid is. Vanuit die Christelike gereg. tigheidsgedagte bestaan daar ' $n$ ander wet van ekonomiese geregtigheid wat die vryheid van eiendom en inisiatief met die verantwoordelikheid teenoor die geheel verbind. Hierdie wet alleen is in staat om die ekonomiese lewe tussen die twee uiterstes deur te stuur.

(Brunner 1948:195, 196; my vertaling)

\section{SLOTOPMERKINGS}

Terwyl mense in die gang van die geskiedenis dikwels God se plek probeer inneem. so dan met God probeer kompeteer in die groot oomblikke van beslissings in die raadsale van owerhede en magte en op die markplein, deur alle beslissingsreg op hulleself te neem en enige mag buiten die menslike te ignoreer, staan ons almal elke oomblik gekonfronteer met die skynbaar onsigbare en tog onverbiddellike mag van die koninkryk van Christus, voor wie almal, alle owerhede en magte, uiteindelik in die geskiedenis sal buig. 
Van verantwoordelikheid voor die geregtigheid van Christus, die Heer van die wêreld, kan niemand wegskram nie en voor die wil van God in die Bybel het niemand 'n neutrale posisie nie. In hierdie lig is dit die taak van die kerk om die samelewing, alle owerhede en magte, ook die ekonomiese magte, te leer van God se etiek, wat 'n hoër wet van die samelewing is en wat bokant alle menslike wette, reëls en norme die toon aangee. Voor God is alle mense ook belangrik: die armes en die rykes, die meerderheid en die minderheid, die gemeenskap en die individu, groepsgebondenheid en onverbondenheid. Die kerk sing nie in die koor van die mode en populariteit en verloën so die geregtigheid van Christus vir alle mense nie. In hierdie verband kan die woorde van Karl Barth met groot waarde aangehaal word: Die kerk 'moet eerder drie maal te veel vir die swakkes opkom as een maal te min, eerder sy stem onaangenaam hard laat weerklink, waar reg en vryheid in gevaar is, as aangenaam sag! Waar dit omgekeerd gaan, gaan dit nie goed met die Christelike gemeente nie' (Barth 1944:34; my vertaling).

Wanneer die Christelike etiek ekonomiese strukture beoordeel, moet onthou word dat daardie strukture die bestuur van die ekonomie bepaal, die verdeling van welvaart vervolgens reguleer en die mense se arbeidsopset reël. Al hierdie sake het dus 'n verband met mekaar wanneer gepraat word van die markplek of ekonomiese strukture. Van Wyk se Christelik-etiese kritiek van die arbeidsituasie in Suid-Afrika is daarom ook relevant vir die gesprek oor ekonomiese strukture, want dit is die ekonomiese strukture (of bestuur van die ekonomie) wat die arbeidsopset daarstel wat onder kritiek kom. In aansluiting by Barth leer hy dat ons menslike arbeid in die algemeen (as arbeid op die omtrek) altyd ruimte moet maak vir en in verband moet staan met daardie sentrale arbeid (as arbeid in die sentrum), wat te doen het met diensbaarheid aan die evangelie van Jesus Christus en die erediens van die kerk en die groot doel van God se werk van skepping, voorsienigheid, versoening en bevryding.

Dit moet ook as prioriteit vir die ekonomiese strukture geld: In die Christelike etiek moet die waardekeuses wat gemaak word in die oprigting van ekonomiese strukture, uiteindelik buig voor Christus se hoër etiese norme en grense wat vir die mens se optredes en keuses en vryhede dargestel word; die koninkryk van die wêreld moet uiteindelik buig voor die koninkryk van Christus (vgl Barth 1968:114122). Vir Van Wyk is die groot doelstelling met menslike arbeid om vrede en geregtigheid te bereik, wat groter is as produksie alleen. Hy beoordeel menslike arbeid en die markplein eties tussen die twee pole van diensgerigtheid en selfgerigtheid. Sodra die swaartepunt van die mens se arbeid wegbeweeg van diensgerigtheid na selfgerigtheid, volg boosheid en selfsug (Van Wyk 1988:74, 75; vgl ook 62, 142, 144). 
Barth wys egter daarop dat die morele motiewe van die mens van nature bepaal word deur hulle eiebelang (selfgerigtheid), en daarom ontstaan byvoorbeeld " $n$ bourgeois, 'n bolsjewistiese, 'n Neger-moraliteit' (Barth 1957:164; my vertaling). Hy sê: '...ons kinders en hulle kinders...moet daarop let, en moet minstens so duidelik soos ons sien, en veel duideliker as ons vaders sien, dat die probleem van die etiek nie alleen die siekte van die mens is nie, maar 'n siekte tot die dood toe' (Barth 1957:150; my vertaling). Die groot probleem van die etiek is dat die mens van nature ' $n$ sondaar is. Barth sê: 'Die aangeleentheid van die morele motief bied alleen aan ons 'n besef van wat die Bybel beskryf as die val van die mens wat alle geskiedenis voorafgaan en bepaal' (Barth 1957:166; my vertaling). Vir Barth is die 'era van die ou etiek vir ewig verby', en wie daarom vandag na sekerheid verlang, moet eers 'onseker' word; oor die verlede van die mens se selfvertroue en vertroue in sy eie vermoëns staan geskrywe: geweeg en te lig bevind (Barth 1957:149). Die ware etiek is vir Barth alleen moontlik in die nuwe mens wat in en deur Jesus Christus geskep word; Jesus Christus is die enigste rede waarom gewaag mag word om te praat van 'n oplossing vir die etiese probleem, omdat $\mathrm{Hy}$ die enigste rede is waarom daar gepraat mag word van verlossing van die dwang van sondaarskap (vgl Barth 1957:180182).

H Antonides, direkteur van die Christian Labour Association of Canada, onderskei 'n drievoudige dimensie van arbeid:

- Arbeid is 'n wyse waarop die mens vir God, sy Skepper, vereer;

* Omdat die een mens van die ander mens afhanklik is, is arbeid ook 'n wyse waarop die mens sy medemens dien;

* Die mens is afhanklik van die natuur wat hom omring en waaruit hy lewe en dit vra van die mens verantwoordelikheid in sy gebruikmaking van natuurlike hulpbronne.

Die konsekwensies van 'n minagting van hierdie drievoudige dimensie van arbeid word sigbaar in vervreemding van God, die mens en van die natuur (Antonides 1989:8). Hierdie drievoudige dimensie raak egter nie die arbeidsterrein alleen nie, maar ook ekonomiese strukture en die hele bestuur van die ekonomie.

Boosheid en selfsug lei na 'n mark en 'n arbeidsopset ('n strukturering van die ekonomie - $\mathrm{d} w \mathrm{~s}$ bestuur van die ekonomie) waarin uitdrukking gegee word aan ' $n$ vervreemde mens en dit is ' $n$ mens wat van sy menswaardigheid beroof word. Die Christelike etiek moet, volgens Van Wyk, 'geregtigheid' in sy volle omvang laat realiseer in die mark en die arbeidsituasie. Daarmee moet selfsug vermy en ingeperk word, sodat bereidheid tot diens in almal se belang gehandhaaf kan word. Die regte doelstellings en strukture vir die samelewing kan die mens se arbeid bevry van onderdrukking en vervreemding en lei tot daardie niveau van vryheid waarin die 
mens hom volledig kan laat opgaan in sy arbeid in diens van God en God se werk. Losgemaak van diens aan God word nie alleen die geestelike dimensie verloor nie, maar ook die menslike dimensie. Verwerping van diensgerigtheid voor God en alle mense lei tot groot hebsug en die euwels van eiebelang. So waarsku Van Wyk dan vervolgens teen die gevare van die kapitalistiese multi-nasionale korporasies, terwyl hy positief staan teenoor klein sake-ondernemings. Hy waarsku teen vryheid en geregtigheid wat in die samelewingstrukture verlore gaan wanneer een groep mense oormatig afhanklik word van 'n ander groep, veral wanneer daar in magteloosheid gestaan word teenoor oormatige selfgenoegsaamheid. Die groeiende gaping tussen ryk en arm is 'n ernstige gevaarteken. Die mark en die arbeidsopset is immers daar vir al sy deelnemers en nie net vir die rykes en hulle in beheer van produksie nie; die massa en die swakstes is ook van belang. Hy wys op die gevare van monopolieë en spreek hom uit ten gunste van verantwoordelike vakbonde. Etiese geregtigheid in praktyk behoort te lei tot 'n vernouing in die gaping tussen ryk en arm. Wat nodig is, is sosiale geregtigheid ten opsigte van arbeiders, saaklike geregtigheid ten opsigte van 'n onderneming se produktiwiteit en winsgewendheid, en natuurgeregtigheid ten opsigte van die gebruik van die natuur se grondstowwe (Van Wyk 1988: 76-151).

Samelewingstukture en veral dan die strukture van die ekonomiese basis van die samelewing, het 'n enorme invloed op menseverhoudinge. In die Christelike etiek moet altyd gewaak word teen 'n gebrek aan grondige denke en 'n verleiding deur ideologiese motiewe. Wanneer die klem op die individu val, word die massa, gemeenskap of groep benadeel; dit is ideologiese denke: liberalisties-kapitalistiese idees. Wanneer die klem op die massa of gemeenskap val, word die individu en minderhede benadeel - en dan is dit wér ideologiese denke: Marxisties-kommunistiese idees. Die Bybel se etiek sien alle mense - individue, groepe, of die gemeenskap in sy geheel - volledig aan, sonder voorrang. Nêrens in die Bybel of in die Christelike etiek is daar grond om te sê dat 'jou naaste liefhê soos jouself' (Matt 22:39) - dit behels 'n gelyke inagneming van alle mense en hulle belange - slegs geld in die verhouding van individu tot individu nie. Die gebod raak inderdaad alle menseverhoudinge en alle verskyningsvorme van die mens: individu tot individu, groep tot groep, individu tot groep (of gemeenskap), groep (of gemeenskap) tot individu, minderhede teenoor meerderhede, meerderhede teenoor minderhede. In alles word gevra na 'n gelyke inagneming van alles en :'mal. In alles word gevra na balans. Die hele balans in die etiek tussen individu en gemeenskap (of groep) was reeds duidelik in die siening van Brunner, na wie hier bo verwys is (sien 3.3). Niemand (een of baie) mag bevoordeel word ten koste van ' $n$ ander (een of baie) nie. Die Christelike etiek verwag so van hulle wat het 'n sosiale gewete en ' $n$ regverdige 
liefde teenoor hulle wat nie het nie, en hulle wat nie het nie, is in die wêreld so vele maal die massa. Dit beteken dat die Christelike etiek balans vra tussen die individu wat in 'n sterk bedingingsposisie staan en die arm massa sonder bedingingsposisie, en die ekonomiese strukture moet buig voor hierdie Christelik-etiese imperatief (vgl 1 Joh 3:17). Die individu mag nie bevoordeel word ten koste van die gemeenskap of groep nie.

Die eis tot balans in die Christelike etiek vergestalt in die Here Christus wat 'hoogmoediges' uitmekaarjaag, 'maghebbers' van trone afruk, 'rykes' met leë hande wegstuur, terwyl aan die ander kant 'geringes' verhoog word en 'behoeftiges' oorlaai word mel goeie gawes (vgl Luk 1:51-53). Die massa (groep/gemeenskap) word opgehef, in balans gebring, volledig in ag geneem teenoor die kragtige individu. Tog sal die Christelike etiek ook nie die geringste en eenvoudigste individu vergeet nie en tree die Here Christus ook in vir sy saak (vgl Luk 17:1,2). Balans op die markplek en 'n gelyke inagneming van almal se belange beteken dus beslis ook nie dat die luiaard (massa of enkeling) toegelaat kan word om op wie ook al te parasiteer nie, want wie nie werk nie, sal nie eet nie (vgl 2 Tess 3:10). Die kapitaalkragtige en hardwerkende individu het beslis ook 'n saak in die Christelike etiek: Ook hy mag nie benadeel word deur die parasitiese massa nie. Die massa (gemeenskap of groep) mag nie bevoordeel word ten koste van die individu nie. Die Christelike etiek vra nogmaals balans!

'Ekonomiese sisteme is daar ter wille van die mens' en nooit andersom nie (Grossman 1974:169; my vertaling). Wanneer daar in die Christelike etiek gehandel word oor die mens, is dit goed om van Barth (en ook ander) te leer om antropologie nooit los te sien van die Christologie nie, maar juis verankerd te sien in die Christologie (vgl Van Niftrik 1951:508). Die Christelike etiek staan so ook nooit los van Christus in die middelpunt nie. Daarom moet ons met Barth saamstem dat die sondaarmens nooit tot werklike etiese optrede in staat sal wees voor die intrede van God in Christus in sy lewe nie (vgl Labuschagne 1987:328-331).

Die ekonomiese basis - watter een ons ook al mag kies vir ons samelewing, in aansluiting by wat hierbo gesê is - omvat uiteindelik drie belangrike verhoudinge:

- Die verhouding met Christus wie se koningskap geld oor hierdie wêreld tot aan die voleinding en vir wie ons in ons arbeid en strukture dien en verheerlik.

- Die verhouding met die medemens (individu of groep) wat in gelyke mate in ag geneem moet word, sodat elke mens op die mark 'n billike en regverdige geleentheid het om 'n bestaan te maak.

- Die verhouding met die natuur wat in verantwoordelikheid benader moet word, om nie net te neem nie, maar ook terug te plaas en te bewaar sodat ons mag voortgaan om te lewe vanuit en in harmonie met die natuur. 
Van hierdie drie verhoudinge moet telkens kennis geneem word in die gesprek van die teologie met die ekonomie oor die markplein en oor ekonomiese strukture as basis van die samelewing. Daar moet ook verwag word dat die Christelike etiek altyd, wat die samelewing en spesifiek die ekonomie betref, hom sal beywer vir strukturele aanpassings in hierdie verband. In die gesprek het dit immers duidelik geword, op mikro- sowel as makrovlak, dat die inset van die Christelike etiek noodsaaklik geword het ten opsigte van die ekonomiese basis van die samelewing, omdat die markplek in Suid-Afrika die potensiaal het om in die onmiddellike toekoms te ontaard: Enersyds kan die oorgrote meerderheid van die bevolking in ongekende armoede en ellende gedompel word en andersyds mag te groot getalle professionele en produktiewe mense die land verlaat. Die gelyke inagneming van almal is belangriker as ooit.

\section{Literatuurverwysings}

Antonides, H 1989. A christian perspective on work and labour relations. Potchefstroom: PU vir CHO.

Barth, K 1944. Belofte en verantwoordelijkheid der Christelijke gemeente in het huidige tijdsgebeuren. Vertaal deur drs A C J van der Poel. Nijkerk: Callenbach.

Barth, K 1957. The Word of God and the word of man. Transl by D Horton. New York: Harper \& Brothers Publishers.

--- 1968. Community, state and church. Transl by A M Hall, G R Howe \& R G Smith. Gloucester, Mass - Peter Smith.

Berger, P L \& Godsell, B 1988. A future South Africa: Visions, strategies and realities. Cape Town: Tafelberg Publishers.

Berki, R N 1975. Socialism. London: Dent \& Sons.

Bonhoeffer, D 1974. No nusty swords - letters, lectures and notes from the collected works. Transl by J Bowden \& P Bethge. London: Collins.

Brandt W (Chairman) 1982. A programme for survival: The report of the Independent Commission on Intemational Development lssues. London: Pan Book.

Brunner, E 1948. Gerechtigheid - een leer van de grondbeginselen ener maatschappelijke orde. Amsterdam: Uitgeverij $W$ ten Have.

Cassen, $\mathrm{R}, \mathrm{Jolly}, \mathrm{R}$ et al 1982. Rich country interests and Third World development. London: Croom Helm Ltd.

De George, R T \& Pichler, J A 1978. Ethics, free enterprise, and public policy - original essays on moral issues in business. New York: Oxford University Press.

Ebenstein, W 1969. Great political thinkers: Plato to the present. Hinsdale, Illinois: Dryden Press. 
Friedman, M 1980. Free to choose. London: Martin Secker \& Warburg Ldd.

Galbraith, J K 1974. Economics and the public purpose. London: André Deutsch Ltd.

- 1977. The affluent society. London: André Deutsch Lid.

Gorbachev, M 1988. Perestroika - New thinking for our country and the world. London: Collins.

Grossman, G 1974. Economic systems. New Jersey: Prentice-Hall Inc.

Gutierrez, G 1974. A theology of liberation: History, politics and salvation. London: SCM Press Ltd.

Hegel, G W F 1955. Grundlinien der Philosophie des Rechts. Hamburg: Verlag von Felix Meiner.

Kee, A (ed) 1974. A reader in political theology. London: SCM Press Lid.

Kinghorn, J, Lategan, B C \& Van der Merwe, C F 1989. Into Africa-Afrikaners in Africa reflect on 'coming home'. Stellenbosch: Centre for Contextual Hermeneutics.

Labuschagne, J P 1987. Die historiese konteks van 20ste Eeuse samelewingsteologieë. Ongepubliseerde doktorale proefskrif, Universiteit van Pretoria.

Locke, J 1965. Two treatises of government (with an introduction and apparatus criticus by Peter Laslett). New York: Mentor Books.

Louw, L \& Kendall, F 1986. South Africa - The solution. Bisho: Amagi Publications.

Marx, K \& Engels, F 1964. On religion. New York: Schocken Books.

-.- 1971. Basic writings on politics and philosophy. London: Collins.

--- 1973. Selected works. London: Lawrence and Wishart.

McLellan, D 1973. Kart Marx - His life and thought. London: Mac Millan.

--- 1974. The thought of Kart Marx. London: Mac Millan.

Parry, G 1978. John Locke. London: George Allen \& Unwin. (Political thinkers no 8).

Potgieter, P C \& Smit, J H 1988. Vermuwing of konfrontasie. Kaapstad: Lux Verbi.

Rousseau, J J 1963. The social contract - and discourses. London: Dent \& Sons.

Samuelson, P A 1976. Economics. Tokyo: McGraw-Hill.

Schumacher, E F 1975. Small is beautiful - A study of economics as if people mattered. London: Abacus Books.

Sinclair, J E \& Parker, R 1983. The strategic metals war: The current crisis and your investment opportunities. New York: Arlington House Publishers.

Smith, A [1776] 1893. An inquin' into the nature and causes of the wealth of nations. London: George Routledge \& Sons. 
Sunter, C 1987. Die Wêreld en Suid-Afrika in die jare negentig. Kaapstad: Human \& Rousseau.

Todaro, M P 1989. Economic development in the Third World. 4th Ed. New York: Longman.

Torres, C 1969. Revolutie: Christelijke opdracht. Utrecht: Bruna \& Zoon.

Van der Walt, B J 1988. Mens- en Christenwees in Afrika. Potchefstroom: PU vir CHO.

Van Niftrik, G C 1951. Zie, de mens. Nijkerk: Callenbach.

Van Peursen, C A 1975. Cultuur in stroomversnelling: Strategie van de cultuur. Amsterdam: Elsevier informatief.

Van Straaten, Z (ed) 1987. Ideological beliefs in the social sciences. Pretoria: HSRC.

Van Wyk, J A 1988. 'n Christelike etiek van die arbied. Pretoria: NG Kerkboekhandel.

Vorster, W S (red) 1990. Morality of the marketplace. Pretoria: UNISA.

Wassenaar, A D 1977. Aanslag op die vrye ekonomie - snelweg na die kommunisme. Kaapstad: Tafelberg uitgewers. 